\title{
PRODUCT DEVELOPMENT AND CHEMICAL COMPOSITION ANALYSIS OF SWEET PICKLED GREEN PAPAYA (Carica papaya)
}

\author{
Arnel B. Millesca \\ Associate Professor, \\ Partido State University, \\ Camarines Sur, \\ Philippines
}

Article D0I: https://doi.org/10.36713/epra6944 DOI No: 10.36713/epra6944

\begin{abstract}
Papaya (Carica papaya) is one of the most popular fruit grown in tropical and sub-tropical regions particularly in the Philippines. It is highly available in the local markets and can also be grown in home backyards. Ripe papaya is fleshy, juicy, and usually consumed raw while the unripe or the green fruit can be cooked or processed. In the Philippines, pickling is the most popular method in utilizing green fruit to produce pickled papaya or locally known as "atchara". Pickled green papaya is a favorite side dish for viands like fried fish, pork, chicken, and the like. As a result, this study is conducted to produce a highly acceptable pickled green papaya as a side dish or as a souvenir or token for visiting tourists in district. Two treatments of brine solution, treatment I (uncooked pickling solution) and treatment II (cooked pickling solution) were performed in producing pickled green papaya. Pickled samples from the two treatments were subjected to sensory evaluation and results showed that taste and aroma for both treatments have no significant differences $(P \leq 0.05)$. However, with regards to color and texture, treatment II obtained a higher scores $(8.17$ and 8.27 , respectively) than treatment I (7.47 and 7.47, respectively). Proximate analysis of treatment II showed a pH of 3.7, 0.30 $\mathrm{g} / 100 \mathrm{~g}$ total fat, $0.50 \mathrm{~g} / 100 \mathrm{~g}$ protein, $0.40 \mathrm{~g} / 100 \mathrm{~g}$ total ash content.
\end{abstract}

KEYWORDS: Pickled papaya, pickling solution, $p H$

\section{INTRODUCTION}

There are various types of foods produced from all over the world using preservation methods. The term "pickle" in Southeast Asia is usually used for fruits and vegetables preserved with vinegar and salt. Preservation methods such as pickling is a technology that is considered the oldest technology (Battock and Ali, 1991) to add flavor and improve the taste of food biologically (Jyoti, 2011; Vichai, n.d.). Euromonitor (2006) defined pickled products as fruits or vegetables preserved in vinegar or brine. Pickles are considered high-acid food. Acid can be added in the form of vinegar or produced naturally by fermentation process. Pickled products are used as food adjuncts and function as appetizers. It also aids in digestion by stimulating the flow of gastric juices.

Papaya (Carica papaya) belongs to the family Caricaceae, a tall herbaceous plant in the genus Carica. Papaya originated in Southern Mexico and Costa Rica. Subsequently, it was introduced as a plantation crop in Australia, Philippines, Hawaii, South Africa, Sri Lanka, India, and in all tropical regions (Krishna et. al, 2008). It is native to the tropical region of America, mainly from southern Mexico to Central America. It is widely cultivated for its fruit, consumed as raw or cooked as vegetable. It is fast growing, high yield and planting is generally done from seed extracted from a ripe fruit (Hawkins, 2007).

Nutritionally, papaya is a rich source of carotenoids, vitamins, minerals (Devaki et al., 2015) and other non-nutrients such as saponins, flavonoids, and phenols (Okon et al., 2017). It is also a source of the proteolytic enzyme papain, particularly the unripe fruit, which aids in digestion of protein. Papain also has many economic and industrial applications (Boshra and Tajul, 2013). Papaya also has property in tenderizing meat which is put to use by cooking to make the meat digestible.

A study by Mendoza (2007) found that papayas have very high levels of potassium $(257 \mathrm{mg} / 100 \mathrm{~g})$ next to banana. The study also reported a high ascorbic acid content $(61.8 \mathrm{mg} / 100 \mathrm{~g})$ of papaya 
which indicates a high antioxidant activity beneficial to human health.

In the Philippines, there are currently seven commercial varieties of papaya sold for human consumption. These are Cavite Special, Morado, Solo, Sinta, Cariñosa, Red Lady and Red Royale. Papayas from these varieties are sold fresh either in its whole or fresh-cut form for direct consumption or sold to food industries for further processing. The fresh-cut form of papayas, however, are gaining popularity with consumers and can often be found in local markets, supermarkets and in food carts (Bureau of Agricultural and Fisheries Standards, 2015).

Unripe papaya can be eaten as a side dish accompanying viands. Processing involves the application of fermentation method to produce pickled green papaya. Pickled papaya is a popular dish made of grated papaya and pickling solution. This dish is usually eaten along with fried or grilled foods such as chicken, fish, pork, beef and seafoods to mitigate its fatty taste. The process of pickling is very simple and there is no need for specific equipment. Salt, sugar, vinegar, and ginger mixed in shredded unripe papaya are the essential or basic ingredients in making pickles. Pickles also contain acetic acid which acts as preservative in order to keep the product quality for a longer time (Nurul \&

Table 1. Pickled green papaya recipe.

\begin{tabular}{l|l}
\hline \multicolumn{1}{c|}{ Quantity } & \multicolumn{1}{c}{ Ingredients } \\
\hline 3 lbs. $(1.4 \mathrm{~kg})$. & Shredded green Papaya \\
\hline 1 teaspoon & Salt \\
\hline $1 / 8 \mathrm{~kg}$ & Ginger \\
\hline 25 grams & 25 grams sliced garlic \\
\hline 7 cups & vinegar \\
\hline 7 cups & brown sugar \\
\hline 1 cup & sliced fresh pineapple \\
\hline $3 / 4 \mathrm{cups}$ & pickled relish \\
\hline $1 / 4 \mathrm{~kg}$ & red bell pepper \\
\hline
\end{tabular}

Preparation of pickled green papaya. Two sets of the recipe shown in Table 1 are prepared for two treatments of pickling process. Raw materials were purchased from the local wet market. Materials such as measuring cups, weighing scale, knife, chopping board, pots, and stove were provided by the Food Laboratory, PSU-San Jose. Two sets of the recipe are weighed and prepared for the formulation of two treatments. Treatment 1 used uncooked vinegar for the pickling solution. Pickled relish and fresh pineapples were added as enhancers. Fresh, firm unripe green papaya were peeled and washed in potable water to remove adhering dirt. Seeds and damaged parts were discarded. The fruits were sliced
Asmah, 2012). As per the result of craving of pickled papaya by the public, this study has been conducted.

The researcher conducted this research because of the absence of single study that has been conducted. The study aims to develop a standard procedure along with the best recipe for making pickled green papaya. More specifically, the study aimed to determine the most acceptable pickling solution formulation for pickled green papaya; evaluate the sensory attributes and acceptability of pickled green papaya; and determine the nutrient value total fat, protein, ash content, and $\mathrm{pH}$ of the product. The findings from this study will increase the availability of scientific data for future reference and for commercialization of pickled products using green papaya or any other fruits and vegetables.

\section{MATERIALS AND METHODS}

The study was conducted at Partido State University - San Jose Campus from March 2018 to March 2019.

Raw materials were purchased from the local market. Proximate analysis such as total fat, protein, ash content, and $\mathrm{pH}$ of the most acceptable pickled green papaya treatment were determined at the service laboratory of Food and Nutrition Research Institute (FNRI).

into convenient pieces and grated using a stainless steel grater. Grated papaya was then tossed in a bowl with salt and then squeezed to discard the juice. It was then washed with water and soaked for 30 minutes to one hour and then squeezed again.

The remaining ingredients were all mixed with the grated papaya then filled in glass jars. For the pickling solution, salt, sugar, and vinegar are mixed together in a separate bowl before adding to the papaya mixture. Glass jars are wiped dry then labelled before storing. Sensory evaluation was conducted one day after processing. Figure 1 summarized the processing flow of pickled green papaya using treatment 1 . 


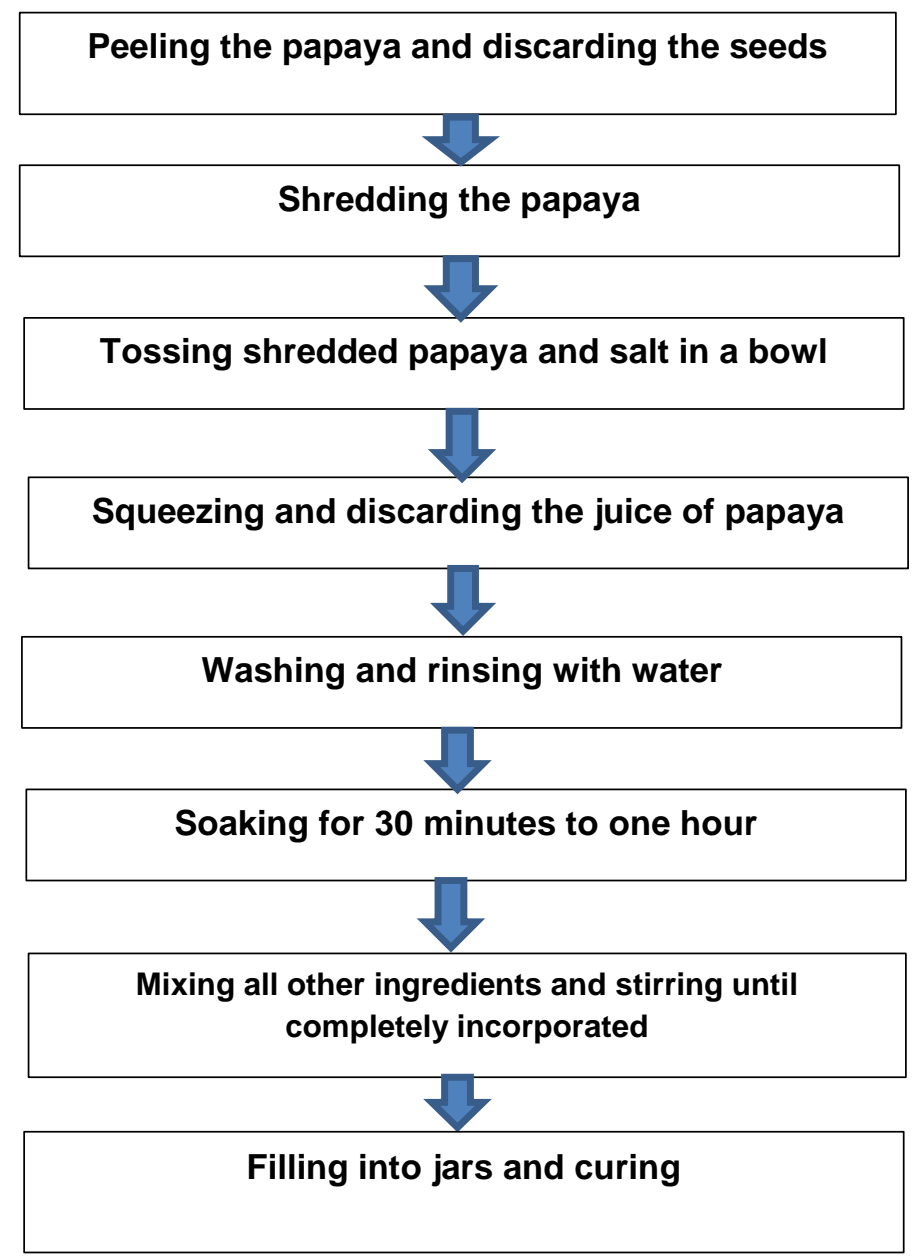

Fig. 1. Process flow of preparing pickled papaya using uncooked pickling solution (Treatment 1).

For treatment 2, the pickling solution consists of vinegar, sugar, ginger, and bell pepper are cooked for 30 minutes before adding to the grated papaya and other ingredients. Processing flow of pickled green papaya using treatment 2 are shown in Figure 2. 
EPRA International Journal of Multidisciplinary Research (IJMR) - Peer Reviewed Journal Volume: 7 | Issue: 5 | May 2021|| Journal DOI: 10.36713/epra2013 || SJIF Impact Factor 2021: 8.047 || ISI Value: 1.188

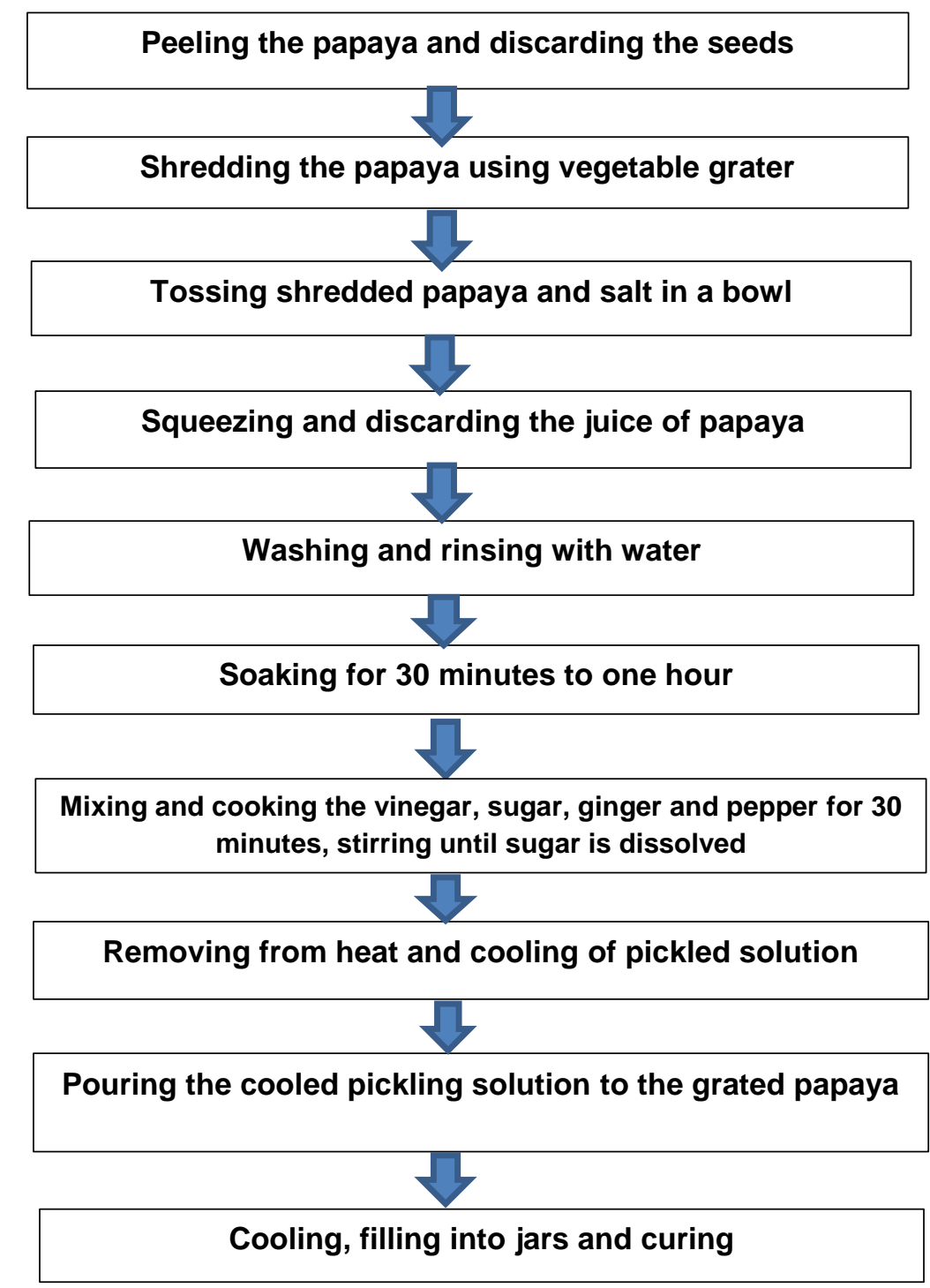

Fig. 2. Process flow of preparing pickled papaya using cooked pickling solution

(Treatment 2).

Sensory evaluation. Pickled green papaya samples were subjected to sensory evaluation using a ninepoint Hedonic scale where 9 indicates "extremely like" while 1 for "extremely dislike". This method was used to assess the color, aroma, texture, and flavor based on the degree of liking. A panel of 30 judges, composed of students, faculty, cooks, vendors and target consumers evaluated the prepared samples to determine the most acceptable product. The samples were coded with three-digit numbers and presented to the panelists. The panelists were asked to rinse their mouths with water after every sample and not to make comments during evaluation to prevent influencing other panelists.

Proximate chemical analysis. Due to the limited facilities in the study place, samples were submitted to service laboratory of DOST-FNRI to determine the total fat, protein, ash content, and $\mathrm{pH}$. Fat content was determined using Soxhlet apparatus while protein was determined by Kjeldahl method. The method for protein content estimated the amount of nitrogen in the sample which was subsequently used to calculate the protein content by multiplying with the factor of 6.25 . Total ash was determined from the residue left after incinerating a $50 \mathrm{~g}$ portion of the sample in a muffle furnace at $550{ }^{\circ} \mathrm{C}$. The $\mathrm{pH}$ were determined using the standard method of the Association of Official Analytical Chemists (AOAC) Official Method. 


\section{RESULTS AND DISCUSSION}

\subsection{Development of pickled papaya}

Pickles can be prepared from a variety of fruit and vegetables and the right amount of spice added. It can be successfully and safely prepared if top-quality ingredients are used. In this study, pickled papaya or atchara is prepared by adding correct proportions of sugar, vinegar, and salt on the grated unripe papaya. Fruits should be green and very firm and must be harvested before the fruit ripens. Ripe papaya has reduced acidity and firmness that results to softening of the flesh making it inappropriate for pickling. However, if it is harvested too early, the pickle will have a bitter milky flavor. Therefore, fully mature but unripe fruit with no signs of spoilage and bruises must be used for the preparation of pickled papaya. Usually, the ends of the fruit is discarded as it contains enzymes that may cause excessive softening of the pickles (Albrecht, 2010).

Process and principle. Lactic acid bacteria (LAB) that are naturally present in fruit convert sugar into lactic acid and enhance the flavor. LAB are generally recognized as safe (GRAS) microorganisms play an important role in food fermentation and preservation. Fermentation converts complex indigestible polymers to digestible carbohydrates (Sareedha et al., 2006). Addition of sugar increases the rate of fermentation or make the product sweeter. Salt helps maintain the firm texture of pickled papaya. Acids lower the $\mathrm{pH}$ and thus inhibit the growth of many micro-organisms. It is more effective against yeast and bacteria than molds. About 20\% vinegar (acetic acid) prevents the spoilage of most products. Though, acid is the main preservative in pickled vegetables and fruit, salt also aids in the growth of desirable bacteria while inhibiting the growth of pathogenic and spoilage microorganisms. Most spoilage bacteria cannot tolerate salt and will die in the brine. Cloudy solution, off-odor, and slipperiness are the usual sign of food spoilage.

Cooking of pickling solution. Acid and heat are destructive to chlorophyll - the pigment responsible for the green color of fruit. Thus, bright green color is not expected in pickled green papaya. Cooking the pickling solution retards the growth of yeasts and mold. Basically, the application of heat inactivates microbial vegetation cells and the addition of acid further prevents the germination of bacterial spores. This will prevent spoilage by microorganisms and therefore extends the shelf life of the food. When the product is preserved properly, risk of food poisoning is very low. Also, storing the pickled products for a longer time improves flavor and increase acidity which serves as a natural preservatives in food.

\subsection{Sensory evaluation of pickled green papaya}

Sensory evaluation is a scientific method used to evoke, measure, analyze, and interpret those responses to product as perceived through the senses of sight, smell, touch, taste, and hearing (Stone and Sidel, 1993; Sharif et. al., 2017). Sensory evaluation or subjective evaluation is an important method to determine the human responses to food especially for new products as it will provide desirable changes to improve the quality of the product. Evaluation includes selected or dominant attributes of the food such as color, aroma, texture, aftertaste, and general acceptability using a scale. This assessment is an ideal method to find out the influence of variation in ingredients or processing. Customer's likeability is a factor for successful introduction and placement of food products in the market.

Pickled samples were evaluated for its color, taste, aroma, and texture. Color is a characteristic that is first perceived by human senses. The color of the food may affect craveability and acceptance and can also be used as a determinant for final selection of food. Taste involves the perceptions of constituents after being dissolved in saliva, oil, or water by the taste receptors in the taste buds (Sharif et al., 2017). Aroma of food also affects the appreciation of foods. The pleasant smell of food makes it more delicious and palatable. Texture is perceived by a combination of senses to evaluate the consistency, softness, chewiness, thickness, and the particle sizes in the food.

Pickled papaya usually has crisp, firm texture with pungent, sweet-sour flavor. Green papaya alone has mild flavor, thus the other ingredients are responsible to its strong flavor. Table 3 shows the mean scores of pickled papaya obtained from sensory evaluation. In general, treatment II obtained higher scores for all the attributes. The color of the pickled papaya can be influenced by various factors such as the color of ingredients (e.g. sugar) added and the type of vinegar used. Higher average score (8.17) was obtained from treatment II (cooked solution) which indicates that judges prefer it than uncooked solution (7.47). One reason could be is that the application of heat dissolves all the sugars and salts and extracts the natural colors of the spices.

For aroma and taste, treatment II obtained higher scores than treatment I. However, statistics showed that the mean scores are not significantly different from each other. It can be said that the judges found no significant differences in both the aroma and taste of two treatments used for pickled papaya. 
EPRA International Journal of Multidisciplinary Research (IJMR) - Peer Reviewed Journal Volume: 7 | Issue: 5 | May 2021|| Journal DOI: 10.36713/epra2013 || SJIF Impact Factor 2021: 8.047 || ISI Value: 1.188

Table 2. Results of 9-point Hedonic Scale for Treatment 1 and 2

\begin{tabular}{|c|c|c|c|c|c|c|}
\hline \multirow[b]{2}{*}{ ATTRIBUTE } & \multicolumn{3}{|c|}{$\begin{array}{c}\text { TREATMENT } 1 \\
\text { (WITH UNCOOKED PICKLING } \\
\text { SOLUTION) }\end{array}$} & \multicolumn{3}{|c|}{$\begin{array}{c}\text { TREATMENT } 2 \\
\text { (WITH COOKED PICKLING } \\
\text { SOLUTION) }\end{array}$} \\
\hline & $\%$ & Score & Rating & $\%$ & Score & Rating \\
\hline \multirow[t]{3}{*}{ Color } & $43 \%$ & 8 & Like very much & $43 \%$ & 9 & Like extremely \\
\hline & $3 \%$ & 3 & Dislike moderately & $18 \%$ & 7 & Like moderately \\
\hline & $3 \%$ & 3 & Dislike moderately & & & \\
\hline \multirow[t]{2}{*}{ Aroma } & $53 \%$ & 8 & Like very much & $46 \%$ & 8 & Like very much \\
\hline & $7 \%$ & 3 & Dislike moderately & $4 \%$ & 6 & Like slightly \\
\hline \multirow[t]{3}{*}{ Texture } & $40 \%$ & 8 & Like very much & $43 \%$ & 9 & Like extremely \\
\hline & $7 \%$ & 6 & Like slightly & $4 \%$ & 6 & Like slightly \\
\hline & $7 \%$ & 2 & Dislike very much & & & \\
\hline \multirow[t]{2}{*}{ Taste } & $43 \%$ & 8 & Like very much & $43 \%$ & 9 & Like extremely \\
\hline & $7 \%$ & 3 & Dislike moderately & $7 \%$ & 6 & Like slightly \\
\hline
\end{tabular}

Table 3. Mean scores of the different sensory attributes of papaya atchara

\begin{tabular}{c|c|c|c|c}
\hline Treatment & Color & Aroma & Taste & Texture \\
\hline Uncooked solution & 7.47 & $7.6^{\mathrm{a}}$ & $7.70^{\mathrm{b}}$ & 7.47 \\
\hline Cooked solution & 8.17 & $8.0^{\mathrm{a}}$ & $7.97^{\mathrm{b}}$ & 8.27 \\
\hline
\end{tabular}

Mean scores within the same column followed by the same superscripts are not significantly different at $\mathrm{P} \leq 0.05$ dislike

Range of scores: 9-extremely like, 1-extremely

Sensory evaluation for texture, on the other hand, have significant difference from each other based on their mean scores. Boiling of pickling solution reduces the water content thus increasing the total soluble solids. Boiling also dissolves salt which reduces water content in the vegetables and hardens the plant pectin therefore preventing softening of the vegetable tissue. Also, application of heat inhibits the activity of pectinase responsible in breaking down pectin. In general, processing or application of heat

Table 4. Proximate Analyses of Green Pickled Papaya with cooked pickling solution

\begin{tabular}{l|c|l}
\hline \multicolumn{1}{c|}{ ANALYTE per 100 g } & RESULT & \multicolumn{1}{c}{ REFERENCE METHOD } \\
\hline Total Fat, g & 0.3 & Acid hydrolysis (Soxhlet) \\
\hline Protein (N x 6.25), g & 0.5 & Automated Kjeldahl Method (Buchi) \\
\hline Ash, g & 0.4 & AOAC 923.05 \\
\hline $\mathrm{pH}$ & 3.7 & AOAC 981.12 (Modified) \\
\hline
\end{tabular}

Papaya belongs to low acid content fruit with its $\mathrm{pH}$ ranging from 5.5 to 6.9 . The resulting $\mathrm{pH}$ of the pickle is 3.7. This is in accordance with US Code of Federal Regulations that pickles acidified with vinegar or acetic acid have final equilibrium $\mathrm{pH}$ of 4.6 or below. Decrease in $\mathrm{pH}$ is attributed to increase acidity. The addition of vinegar greatly affects the lowering of $\mathrm{pH}$ because vinegar are naturally acidic with $\mathrm{pH}$ range of 2 to 3 . may alter the sensorial properties, so changes in texture, color, or palatability are perceivable.

\subsection{Chemical composition of pickled green papaya}

Table 4 shows the results of proximate analysis of the most acceptable treatment for pickled green papaya and the reference method for every analysis. Results showed that pickled papaya is not a good source of fat and protein. Slavin and Lloyd (2012) reported that fruits in general are low in protein and mineral constituents. They also reported that fruits are generally low in fat content and hence, recommended in weight-reducing diet.

\section{CONCLUSION AND RECOMMENDATIONS}

In this study, pickled green papaya was prepared using two different treatments. Treatment I for uncooked pickling solution and Treatment II for cooked pickling solution. Sensory evaluation was conducted to determine the most acceptable among the sample treatments. The most acceptable sample 
was subjected to chemical analyses. Total fat, protein, ash and $\mathrm{pH}$ of pickled green papaya were also determined. The results of the study revealed that, cooking the pickling solution is more acceptable than uncooked. Chemical analysis showed that pickled papaya is not a good source of fat and proteins. Final product showed a low $\mathrm{pH}$ values which is attributed to its acidity.

Further studies must be conducted on the shelf life that be carried out weekly to determine change in quality with storage time. Microbial analysis can also be conducted to determine the presence of visible decay such as fungal growth, gas production, and offflavor over time. Yield, cost of production, and suggested price must be accounted to determine the marketability of green pickled papaya. To assess the market acceptability or sale ability, the product will be sold in the school canteen, caterers and other food outlets. Promotional activities will also be done to further determine the demand and sale of the said product. This may serve as preparation for the commercialization of green pickled papaya.

It is also recommended to prolong the fermentation period of pickled green papaya. Taste, flavor, texture, and consistency improve with increased storage period. Pickled products usually develop flavor over a four- to five-week period. Fruits and vegetable fiber are further broken down during storage thus, increasing digestibility of pickled products. Acidity also increase due to lactic acid fermentation. Lactic acid bacteria such as lactobacilli are good bacteria that are beneficial to human health.

\section{REFERENCES}

1. Albrecht, J.A. (2010). Let's Preserve: Fermented and Pickled Foods. University of NebraskaLincoln.

2. Battock, M. \& Ali, S.A. (1991). Fermented fruits and vegetables: A global perspective. FAO: Rome.

3. Boshra V, Tajul AB. (2013). Papaya - an innovative raw material for food and pharmaceutical processing industry. Health $\begin{array}{llll}\text { Environ. } & \text { J., } & \text { 68-75. }\end{array}$ http://www.hej.kk.usm.my/pdf/HEJVol. 4No.1/Article07.pdf

4. Devaki C.S., Farha Samreen, F., Prakash, J. (2015). A Review on Composition, Processed Products and Medicinal Uses of Papaya (Carica Papaya L.). International Journal of Food, Nutrition and Dietetics Volume 3 Number 3, September - December 2015.

5. Euromonitor (2006). Packaged food in Malaysia. London: Euromonitor International.

6. Ismail, N. (2015). Preliminary Study On The Marketing Of Pickles In Malaysia. Journal of Agribusiness Vol. 7 (2015): 60-82.

7. Jyoti, P. T. (2011). Prospects of Asian Fermented Foods in Global Markets. The 12th ASEAN Food
Conference 2011, 16-18 June, 2011. BITEC Bangna, Bangkok, Thailand.

8. Krishna, K.L., Paridhavi, M. and Patel, J.A. (2008). Review on nutritional, medicinal and pharmacological properties of Papaya (Carica papaya). Natural Product Radiance 7(4):364373.

9. Mendoza, E. M. (2007). Development of Functional Foods in the Philippines. Food Sci. Technol. Res. 13 (3), 179-186.

10. Nurul, S. R. and Asmah, R. (2012). Evaluation of antioxidant properties in fresh and pickled papaya. International Food Research Journal. 19 (3), $1117-1124$.

11. Okon, W.I., Ogri, A.I., Igile, G.O. and Atangwho, I.J. (2017). Nutritional quality of raw and

12. processed unripe Carica papaya fruit pulp and its contribution to dietary diversity and food security in some peasant communities in Nigeria Int. J. Biol. Chem. Sci. 11(3): 1000-1011

13. Pe'rez-Di'az, I. M., F. Breidt, R. W. Buescher, F. N. Arroyo-Lo' pez, R. Jime' nez-Dı'az, A Garrido Ferna' ndez, J. Bautista Gallego, S. S. Yoon and S. D. Johanningsmeier. (2013). Compendium of Methods for the Microbiological Examination of Foods chapter 51 Fermented and Acidified Vegetables

14. Sareedha, P; Anburani A. and Samruban. J. (2006). Influence of integrated nutrient management on growth of gherkin (cucumis sativus l.) Cv. Ajax hybrid. Vegetable Sci. 2006; Vol. 33(2), 196-197.

15. Saroj \& Singh, K. K. (2018). Standardization of recipe and method for mango pickle. International Journal of Chemical Studies. 6(2), 2033-2037.

16. Shanta, F. H., Rajib, R. R., Alim, M. A., \& Haque, M. R. (2014). Studies on the preparation of stem amaranth pickle. J. Bangladesh Agril. Univ. 12(1), 177-182.

17. Sharif, M.K. Butt, S.M., Sharif, H.R., and Nasir, M. (2017). Sensory Evaluation and Consumer Acceptability. Handbook of Food Science and Technology. 362-386

18. Slavin JL, Lloyd B. 2012. Health benefits of fruits and vegetables. Adv. Nutr., 3: 506- 516.

19. Stone, $H$ and Sidel, J.L. (1993). Sensory Evaluation Practices, 2nd ed. Academic Press Inc., San Diego, CA 